\title{
人工膝関節置換術後成績不良症例の検討
}

\author{
九州大学整形外科 \\ 泉敏 弘・三 浦 裕 正 \\ 喜 名 政 浩・杉 岡 洋一 \\ 福岡聥信病院整形外科 \\ 川村 秀 哉
}

\section{An analysis of Failed Total Knee Prostheses}

by

\author{
Toshihiro Izumi, Hiromasa Miura, Masahiro Kina \\ and Yoichi Sugioka \\ Department of Orthopedic Surgery, Kyushu University, \\ Fukuoka, Japan
}

\section{Hideya Kawamura}

Department of Orthopedic Surgery, Fukuoka Teisin Hospital

Total knee arthroplasty is indicated for the treatment of osteoarthritis. The number of operated cases is increasing, and we report our experience with failed total knee prostheses. We had 9 failed total knee joints, of which 3 were Porous coated anatomic (PCA) type, 2 were MillerGalante (MG) type. 3 were unicompartmental (UKA), and 1 was the Kinematic type. Failure included patellar subluxation, patellar fracture, and tibial subsidence with loosening in the PCA prostheses ; instability and patellar subluxation with metallosis in the MG prostheses ; loosening and dislodgement of the component in UKA and deep infection in a Kinematic prosthesis. Some failures after TKA might result from inappropriate component designs and/or inadequate surgical techniques.

Key words : total knee arthroplasty (人工膝関節置換術), complication (合併症), Porous-coated anatomic

進行した変形性膝関節症において，人工膝関節置換 術が施行されているが，その合併症も少ないものでは ない. 合併症としては人工関節のゆるみ, 膝不安定性, コンポーネントの破損, 磨耗, あるいは深部感染等が 報告されている1)-5).

今回, 他院にて人工関節置換術を施行された症例も 含めて当科において経験した人工膝関節術後成績不良 例について検討を加えた。

\section{対象}

revision を必要とする人工膝関節術後成績不良症例
は 1987 年より 1994 年までに 9 例 9 関節であり, 機種別 には porous-coated anatomic (PCA) 3 例 3 関節, Miller-Galante (MG) 2 例 2 関節, 片側置換型人工関 節 (UKA) 3 例 3 関節，Kinematic 1 例 1 関節であった。 さらに，PCA 型においては subsidence を伴ったゆ るみを経験したので, 当科における症例を検討した。 1983 年 11 月より 1987 年 7 月までに置換術を行った PCA 型は 17 例 22 関節であった。

結果

機種別にみた合併症は, PCA 症例においては 22 関 
表 failure 症例

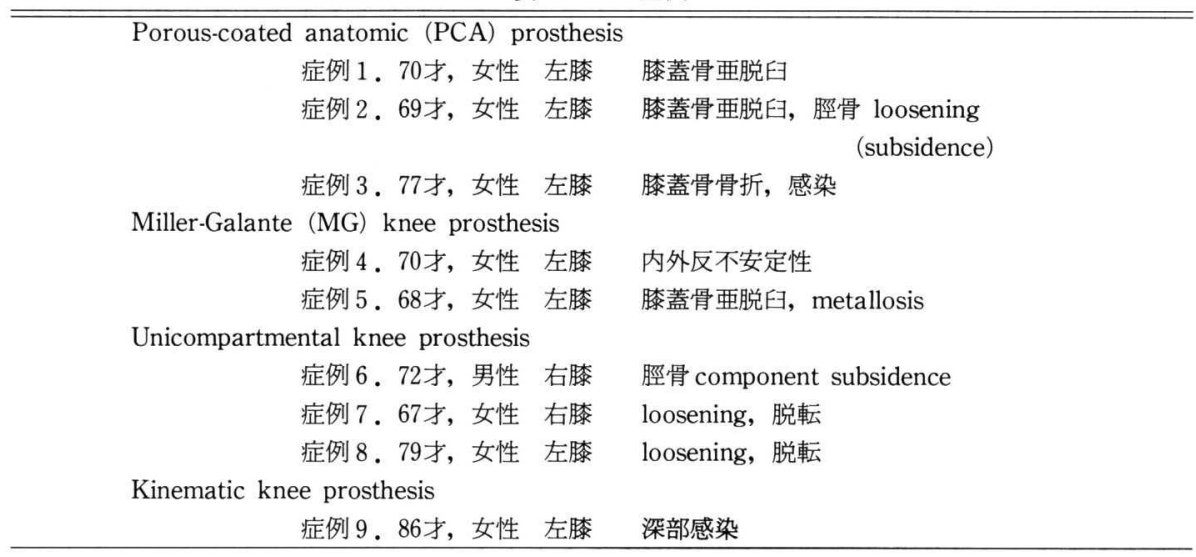

節中 3 関節に生じ, 膝蓋骨亜脱臼, 脛骨コンポーネン 卜の subsidence, 膝蓋骨骨折があった。MG 症例に おいては 60 関節中 2 関節に生じ, 脛骨インサートが 薄く内外反不安定性を示した症例, 膝蓋骨亜脱臼によ り膝蓋骨 HDP の破損をきたし metallosis を生じた症例 があった. UKA 症例ではコンポーネントのゆるみ, 脱 転, 脛骨コンポーネントの subsidence があった (表).

症例 $2: \mathrm{PCA}$ 症例, 69 才, 女性で昭和 60 年に PCA を用いて左人工関節置換術を行っているが, 術 後 5 年で subsidence を生じた。初回手術時に脛骨コ ンポーネントが前傾に設置されていた (図 1). 術後 9 年における revision 時の所見では脛骨コンポーネ ントの HDPが磨耗し, 金属トレイが露出していた。 また, 脛骨コンポーネントの周囲には肉芽が入り込み, コンポーネントは異常可動性を示していた。

症例 4:MG 症例, 70 才, 女性で初回手術時に脛 骨コンポーネントのインサートが薄かったために術後 半年より不安定性が増強してきた (図 2)。この症例 では厚いインサートに置換した。

当科において PCA 型を用いて人工膝関節置換術を 行った症例は, 1983 年 11 月から 1987 年 7 月までに 17 例 22 関節あり, 脛骨コンポーネントの subsidence を生じた症例が 3 例 3 関節であった。 脛骨コンポーネ ントをセメントを使用しないでスクリュー固定した 13 関節のうち 3 関節に沈み込みを生じており,うち 2 関節は脛骨コンポーネントが前傾に設置されていた。 しかしながら, 脛骨コンポーネントをセメント固定し た 9 関節においては, コンポーネントが前傾に設置さ れた 3 関節も含めて subsidence は生じていなかった。

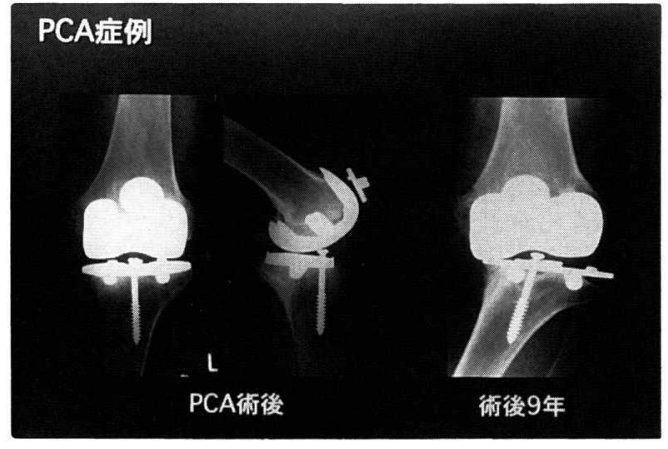

図 1 症例 2

左人工滕関節置換後 5 年で subsidence を生じてきた.

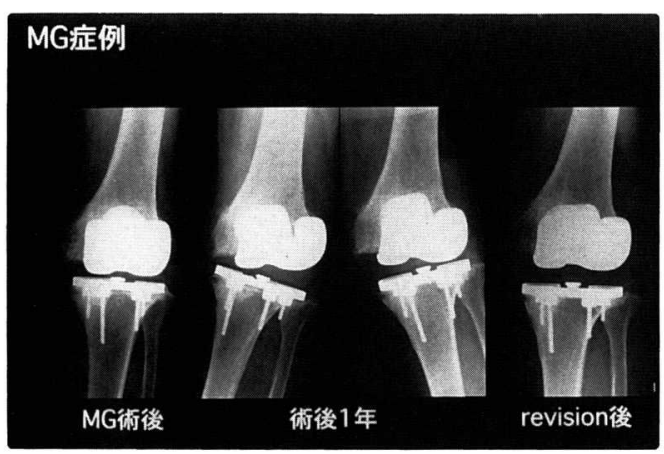

目 2 症例 4

左人工滕関節置換後半年で内外反動摇性が堌強してきた。

考

\section{察}

人工膝関節置換術後の合併症には, 膝伸展機構に関 
するものとして膝蓋骨要脱臼, 膝蓋骨骨折, 膝蓋骨コ ンポーネントの破損等があるが2), 我々の経験した症例 においても膝蓋骨に問題がある症例が 4 例と多かった。

PCA 型においては subsidence を伴ったゆるみを経 験したが, この原因としては, 患者の活動性, コンポー ネントのデザイン及び材質，手術手技があげられる. $\mathrm{Knahr}^{1)}$ らは PCA 型脛骨コンポーネントに骨セメン 卜を用いていない症例を検討し正確な手術手技による 初期固定の重要性を報告しているが, 我々の経験した セメント固定例では前傾に設置されていても subsidence を生じていなかった。初期の PCA 型脛骨 コンポーネントのデザインは前後径が短くコンポーネ ントが前方の骨皮質にかからない欠点があり，骨セメ ントを用いないで前傾に設置されると subsidence を 生じることが考えられた。

\section{参 考 文 献}

1) Knahr, K., Salzer. M., and Schmidt, W. : A radio- logical analysis of uncemented PCA tibial implants with a follow-up period of $4-7$ years. J. Arthroplasty. 5 : 131-141, 1990.

2) Rand, J. A. : The patellofemoral joint in total knee arthroplasty. J. Bone Joint Surg., 76A : 612-619, 1994.

3) Rorabeck, C. H., Bourne, R. B., Lewis, P. L., and Nott, L. : The Miller-Galaente knee prosthesis for the treatment of osteonecrosis. J. Bone Joint Surg., 75A : 402-408, 1993.

4）佐々木鉄人：人工膝関節の合併症と対策. 整形外科 MOOK, 61:197-206, 1991.

5) Tsao, A., Mintz, L., McRae, C. R., Stulberg, S. D., and Wright $\mathrm{T}$. : Failure of the porous-coated anatomic prosthesis in total knee arthroplasty due to severe polyethylene wear. J. Bone Joint Surg., 75A : 19-25, 1993. 